\title{
Designing a Notation for the Senses
}

\author{
Dr Raymond Lucas
}

University of Strathclyde

'If you desire only to possess a graceful accomplishment, to be able to converse in a fluent manner about drawing, or to amuse yourself listlessly in listless hours, I cannot help you: but if you wish to learn drawing that you may be able to set down clearly, and usefully, records of such things as cannot be described in words, either to assist your own memory of them, or to convey distinct ideas of them to people; if you wish to obtain quicker perceptions of the beauty of the natural world, and to preserve something like a true image of beautiful things that pass away, or which you must yourself leave; if, also, you wish to understand the minds of great painters, and to be able to appreciate their work sincerely, seeing it for yourself, and loving it, not merely taking up the thoughts of other people about it; then I can help you, or, which is better, show you how to help yourself.' (Ruskin, J. 1971:25)[1]

\section{Introduction}

This paper is drawn from the work of the Multimodal Representation of Urban Space research project for the UK's AHRC and EPSRC under the Designing for the 21st Century stream of projects. The aim of the project is to understand the role of the non- visual senses in our experience of urban spaces. We then intend to design tools to allow for crafting urban environments to respond to these other senses.

Understanding the role of the non-visual senses is difficult, as there is at present no recording medium for the olfactory, gustatory, tactile or even aural environment which is useful to the practice of urban design. In any case, recording has a different aim from drawing and notation. The reason for this rejection of recording technologies can be understood through the following observation by Jorge Luis Borges:

'The taste of the apple... lies in the contact of the fruit with the palate, not in the fruit itself; in a similar way... poetry lies in the meeting of poem and reader, not in the lines of symbols printed on the pages of a book. What is essential is the aesthetic act, the thrill, the almost physical emotion that comes with each reading.' Borges, J. L. Foreword to Obra Poética cited in Pallasmaa, J. 1996:6 [2]

When using audio recording equipment, all one records is the sound that the microphone technology can pick up. Even when using equipment that mirrors the positioning of human ears such as binaural microphones, it is clear that many of the effects of 
aural perception are not replicated. These differences may include memory or attention functions of perception, meaning that situations such as the 'Cocktail Party' effect where one picks up on your own name being spoken across a noisy party are not fully replicated by recordings.

This all moves us away from a recording technology to a more prosaic solution: drawing and notation (although this still constitutes a technology, of course). This is also important methodologically, as it places our proposal firmly in the realms of creative practice rather than scientific understanding. As such, we are not looking to collate the responses of a wide variety of respondents (although this is possible within the system developed) in order to find a common understanding of a place, but to rely upon the observations of a designer in making informed decisions. There is a crucial role for community engagement of course, but this comes at a different stage of the design process.

\section{What is Notation?}

Dividing up the various forms of inscriptive practice is a difficult task, defining the difference between sketches, drawings, drafting, notation, diagramming and mapping is an activity fraught with blind alleys, problems of definition and intent. Rather than see each of these as a different subset of inscriptive practice, I have come to understand each as a potential property of any inscription, so that an architectural drawing, for example, can be said to have the interplay of white space and line inherent to drawing, the instructional quality of notation, the scale and ruled quality of drafting, and the pictorial representation of a sketch all within the same set of marks on paper. Many other qualities can be found within this drawing, and others can be said to be factors by virtue of their denial or absence. Each of these qualities is nested within the artifact, coexistent with, and essential to each other [3].

'Because a plan is a drawing, with lines and angles subject to continuous variation, the first guess would be that it is technically a sketch. But on the plan are measurements in words and figures. This suggests that we have here a combination of sketch and script. But I think this again is wrong. In the first place, the drawing is used only to indicate the relataive location of elements and measurements. Careful drawing to scale is merely for convenience and elegance; a rough and distorted version with the same letters and numerals, qualifies as a true copy of the most precisely drafted blueprint, prescribes the constitutive properties as rigorously, and has the same buildings as compliants... Thus although a drawing often counts as a sketch, and a measurement in numerals as a script, the particular selection of drawing and numerals in an architectural plan counts as a digital diagram and as a score.' (Goodman, N. 1976:218-219)[4]

Nelson Goodman's work on Languages of Art (a title that Goodman is somewhat embarrassed by, given the connotations of language as a term) describes in great detail the distinction between scripts, sketches and scores as creative activities. These definitions are particularly useful in terms of activities and practices rather than completed, crystalline objects [5].

In Goodman's system, sketches are working documents, but not in any language system, rather being in an internalised system without semantic or syntactic differentiation (Goodman 1976:192). It is the relationships 
of the elements pictorially that are of primary concern in a sketch, and, unlike a score, where some elements of the inscription are redundant, none of the pictorial elements of a sketch can be discarded as irrelevant. Furthermore, the sketch is a work rather than something that determines a later performance.

'In short, the sketch-as a sketch-differs from the score not in functioning as a character in a language of a different kind but in not functioning as a character in a language at all. The notational language of musical scores has no parallel in a language (notational or not) of sketches.' (Goodman 1976:193-194)

Score and notation are conflated by Goodman, who states that the score is a 'character in a notational system' (1976:177). Scores are understood to have performances compliant to them: scores are to be enacted and acted upon, suggesting that a notation is a set of instructions. This performance is understood to be an artwork in its own right, as is the production of the score, as Goodman cites Sir George Thomson's views on experimental science:

'You see no experiment can be repeated exactly. There will always be something different.... What it comes to when you say you repeat an experiment is that you repeat all the features of an experiment which a theory determines are relevant. In other words you repeat the experiment as an example of the theory.' (Sir George Thomson cited in Goodman 1976:177).

This recalls Bergson's statements in The Creative Mind [6] (1992:100) regarding the essential difference between speculative and creative problems, stating that the speculative problem such as a mathematical formula has its solution present as soon as the problem is correctly and properly stated. The creative problem, by contrast, has the time spent on the activity enfolded into the solution: it cannot exist without the creative practice being engaged in, as decisions and modifications are so open and constantly in flux that the temporality is inherent in the result. The speculative problem is absolute and has a right and wrong answer defined as the possible rather than multiple potential solutions, as is found in the creative process. In this context:

'the possible is only the real with the addition of an act of mind which throws its image back into the past, once it has been enacted.' (Bergson 1992:100)

This project seeks to find a notation for the sensory experience of urban environments for these very reasons. Rather than to draw the senses, we aim to produce scores for the senses, scores that allow for creative replication through a common code or rudimentary language. This is to allow for the essential design activity of both understanding and recording phenomenological experiences, and then to establish patterns from these recordings that can be used to form new design solutions.

\section{Attention and a Taxonomy for the Senses}

The senses are not a given category, of course, but abstractions that have become deeply embedded in our thinking about our bodies and the external world. Making sense of these sensations is not surprising, of course, and many of the systems categorising the sesnse agree on a number of fundamental qualities. The fact that the sensory modalities themselves remain up for grabs is a useful opportunity for our project of a notation for the senses specific to the experience of the urban environment. This specificity makes the task possible in many regards, as it narrows our concern substantially. This is methodologically crucial, allowing a man- 
ageable set of sensations to be selected.

The alternative to this is the parable by Jorge Luis Borges, On Exactitude in Science [7] where a ruler sets his cartographers to make an exact map of his territory. The resulting map is so exact in fact that it covers that territory completely. Our task in notation is not only to record information, but also to edit it, allowing only what is relevant and useful.

Taxonomy, listing and categorisation is itself a problematic activity, particularly as it specifies what, in many regards, cannot be specified. It also divides the sensorium, which is experienced as a totality with corroboration and overlapping between senses. This artificiality is not an insurmountable problem, however. The task is, in itself, an artifice that should be recognised and understood rather than rejected or hidden. This artifice allows for a sytematisation of the senses, a functional and operationalising system which facilitates further actions such as design.

One such writer is the essayist and novelist Junichiro Tanizaki in his classic work on Japanese aesthetics, In Praise of Shadows [8]. Tanizaki takes on the notion of the shadow, finding its qualities throughout architectural design, but also in terms of material quality, food, theatre and other arts. This approach unites the sensorium, and borrows concepts across modalities. As an essay on aesthetics, Tanizaki reminds us that the basis of an aesthetic response (where it even exists as such) is a deeply encultured response to phenomena, and open to multiple approaches and variations in the concept of what is desirable or beautiful.

'Every time I am shown to an old, dimly lit, and, I would add, impeccably clean toilet in a Nara or Kyoto temple, I am impressed with the singular virtues of Japanese architecture. The parlor my have its charms, but the Japanese toilet truly is a place of spiritual repose. It always stands apart from the main building, at the end of a corridor, in a grove fragrant with leaves and moss. No words can describe that sensation as one sits in the dim light , basking in the faint glow reflected from the shoji, lost in meditation or gazing out at the garden. The novelist Natsume Soseki counted his morning trips to the toilet a great pleasure, 'a physiological delight' he called it. And surely there could be no better place to savor this pleasure than a Japanese toilet where, surrounded by tranquil walls and finely grained wood, one looks out upon blue skies and green leaves.

As I have said there are certain prerequisites: a degree of dimness, absolute cleanliness, and quiet so complete one can hear the hum of a mosquito. I love to listen from such a toilet to the sound of softly falling rain, especially if it is a toilet of the Kanto region, with its long, narrow windows at floor level; there one can listen with such a sense of intimacy to the raindrops falling from the eaves and the trees, seeping into the earth as they wash over the base of a stone lantern and freshen the moss about the stepping stones. And the toilet is the perfect place to listen to the chirping of insects or the song of the birds, to view the moon, or to enjoy any of those poignant moments that mark the change of the seasons. Here, I suspect, is where haiku poets over the ages have come by a great many of their ideas.' (Tanizaki, J, 2001:9)

This drive to the poetic in describing a total experience of space is a common response, of course, and fulfills certain of the requirements of communicating this experience of being in space as an immersive experience of being in space rather than on a surface. This is a distinction made by Ingold [9] in 
his work on perception, and is borne out by architects such as Peter Zumthor [10] in describing the manifesto for his architecture as the creation of atmospheres. In this extended essay, a number of the challenges to our project at large are given form.

As well as these holistic approaches to complete sensoriality, a number of texts draw upon one sense, particularly an alternative to vision, which is given a place of priority, a place that is ripe to be usurped. The most likely candidate to overthrow vision is hearing. Sound is uniquely developed as a field thanks largely to the pioneering work of $\mathrm{R}$ Murray Schafer on the Soundscape. Schafer is, of course, only the first, and a field of sound design and appreciation of the urban environment has developed across a variety of disciplines. Rather than give a survey of this work by the likes of Blesser [11], Augoyard [12], DeNora [13] and Bull [14], I shall instead consider taking the aural as a starting point for the other senses.

This may at first seem to be replacing the visual bias with another, but is intended purely as an exercise in thinking and perceiving. Were the other senses to be considered in terms of sound, a series of other qualities are revealed. Foremost amongst these is the impermanent and fleeting nature of sensation. Rather than fixed, total and permanent as vision might suggest, the senses (and I include seeing in this) are contingent to a large number of factors such as season, weather, time of day, social and cultural events, and many more temporal and rhythmical variables.

This focus on the temporal recalls the work of Bergson once again, where everything can be understood through duration. It also suggests a more useful theoretical text by Henri Lefebvre, Rhythmanalysis [15] in which Lefebvre posits rhythm as an alternative concept to that of geometry. As a character, the rhythmanalyst is described thus:
'For him, nothing is invisible. He hears the wind, the rain, storms; but if he considers a stone, a wall, a trunk, he understands their slowness, their interminable rhythm. This object is not inert: time is not set aside for the subject. It is slow only in relation to our time, to our body, the measure of rhythm. An apparently immovable object, the forest, moves in multiple ways: the combined movements of the soil, the earth and the sun.' (Lefebvre 2004:20)

Lefebvre's method encourages a certain aloofness, like an early detached ethnographer. The site of observation is suggested as a balcony, with a good view of the area in question. Our method would critique this part of Lefebvre's rhythmanalysis, preferring to place the notator in the action of the urban environment. I would even suggest that the action of memory in recalling an event soon after its happening would be preferable to the aloof method proposed by Lefebvre here. Despite this problem, there is a great deal to recommend Lefebvre's theory of rhythm. The phenomenological basis of the work is clear, to the point of incorporating one's own bodily rhythms into the process: an awareness of the heart rate and pumping of blood around the body, the action of breathing.

There is a great deal more to say about Lefebvre than we have space for here, the concept of social dressage, for example, informs which gestures are encultured into a city. This can be particularly important as in examples such as subway and metro systems where the spatial configuration is very similar from London to Paris, New York, Moscow or Tokyo. The dressage of the participants in these quotidian events are however, completely different from one city to another.

'Observe the street, from time to time, with some concern for system perhaps. 
Apply Yourself. Take your time.

Note down the place: the terrace of a café near the junction of the Rue de Bac and the Boulevard Saint-Germain

the time: seven o'clock in the evening

the date: 15 May 1973

the weather: set fair

Note down what you can see. Anything worthy of note going on. Do you know how to see what's worthy of note? Is there anything that strikes you?

Nothing strikes you. You don't know how to see.

\begin{tabular}{|c|c|c|c|c|c|c|}
\hline Name & Mode of Attention & Receptive Units & $\begin{array}{l}\text { Anatomy of the } \\
\text { Organ }\end{array}$ & $\begin{array}{l}\text { Activity of the } \\
\text { Organ }\end{array}$ & Stimuli Available & $\begin{array}{l}\text { External } \\
\text { Information } \\
\text { Obtained }\end{array}$ \\
\hline $\begin{array}{l}\text { The basic } \\
\text { orienting system }\end{array}$ & $\begin{array}{l}\text { General } \\
\text { orientation }\end{array}$ & $\begin{array}{l}\text { Mechano- } \\
\text { receptors }\end{array}$ & $\begin{array}{l}\text { Vestibular } \\
\text { organs }\end{array}$ & $\begin{array}{l}\text { Body } \\
\text { equilibrium }\end{array}$ & $\begin{array}{l}\text { Forces of } \\
\text { gravity and } \\
\text { accelleration }\end{array}$ & $\begin{array}{l}\text { Direction of } \\
\text { gravity, being } \\
\text { pushed }\end{array}$ \\
\hline $\begin{array}{l}\text { The auditory } \\
\text { system }\end{array}$ & Listening & $\begin{array}{l}\text { Mechano- } \\
\text { receptors }\end{array}$ & $\begin{array}{l}\text { Cochlear } \\
\text { organs with } \\
\text { middle ear and } \\
\text { auricle }\end{array}$ & $\begin{array}{l}\text { Orienting to } \\
\text { sounds }\end{array}$ & $\begin{array}{l}\text { Vibration in the } \\
\text { air }\end{array}$ & $\begin{array}{l}\text { Nature and } \\
\text { location of } \\
\text { vibratory events }\end{array}$ \\
\hline $\begin{array}{l}\text { The haptic } \\
\text { system }\end{array}$ & Touching & $\begin{array}{l}\text { Mechano- } \\
\text { receptors and } \\
\text { possibly } \\
\text { thermo- } \\
\text { receptors }\end{array}$ & $\begin{array}{l}\text { Skin (including } \\
\text { attachments } \\
\text { and openings), } \\
\text { joints (including } \\
\text { ligaments), } \\
\text { muscles } \\
\text { (including } \\
\text { tendons) }\end{array}$ & $\begin{array}{l}\text { Exploring of } \\
\text { many kinds }\end{array}$ & $\begin{array}{l}\text { Deformation of } \\
\text { tissues, } \\
\text { configuration of } \\
\text { joints, } \\
\text { stretching of } \\
\text { muscle fibres }\end{array}$ & $\begin{array}{l}\text { Contact with } \\
\text { the earth, } \\
\text { mechanical } \\
\text { encounters, } \\
\text { object shapes, } \\
\text { material states, } \\
\text { solidity or } \\
\text { viscosity }\end{array}$ \\
\hline \multirow[t]{2}{*}{$\begin{array}{l}\text { The taste-smell } \\
\text { system }\end{array}$} & Smelling & $\begin{array}{l}\text { Chemo- } \\
\text { receptors }\end{array}$ & $\begin{array}{l}\text { Nasal cavity } \\
\text { (nose) }\end{array}$ & Sniffing & $\begin{array}{l}\text { Composition of } \\
\text { the medium }\end{array}$ & $\begin{array}{l}\text { Nature of } \\
\text { volatile sources }\end{array}$ \\
\hline & Tasting & $\begin{array}{l}\text { Chemo- and } \\
\text { mechano- } \\
\text { receptors }\end{array}$ & $\begin{array}{l}\text { Oral cavity } \\
\text { (mouth) }\end{array}$ & Savouring & $\begin{array}{l}\text { Composition of } \\
\text { ingested objects }\end{array}$ & $\begin{array}{l}\text { Nutritive and } \\
\text { biochemical } \\
\text { values }\end{array}$ \\
\hline $\begin{array}{l}\text { The visual } \\
\text { system }\end{array}$ & Looking & Photo-receptors & $\begin{array}{l}\text { Ocular } \\
\text { mechanism } \\
\text { (eyes with } \\
\text { intrinsic and } \\
\text { extrinsic } \\
\text { muscles, as } \\
\text { related to the } \\
\text { vestibular } \\
\text { organs, the } \\
\text { head, and the } \\
\text { whole body) }\end{array}$ & $\begin{array}{l}\text { Accommodatio } \\
\text { n, pupilary } \\
\text { adjustment, } \\
\text { fixation, } \\
\text { convergence } \\
\text { exploration }\end{array}$ & $\begin{array}{l}\text { The variables of } \\
\text { structures in } \\
\text { ambient light }\end{array}$ & $\begin{array}{l}\text { Everything that } \\
\text { can be specified } \\
\text { by the variables } \\
\text { of optical } \\
\text { structre } \\
\text { (information } \\
\text { about objects, } \\
\text { animals, } \\
\text { motions, events, } \\
\text { and places) }\end{array}$ \\
\hline
\end{tabular}

Table 1: Gibson's perceptual systems chart [17].
You must write about out it more slowly, almost stupidly. Force yourself to write down what is of no interest, what is most obvious, most common, most colourless.' (Perec, G. 1997:50)

A similar method is explored by the writer Georges Perec in his essay The Street [16]. As an exercise in perception, Perec asks us to 'decipher a bit of the town' (1997:52) and to concentrate on the quotidian and obvious, in order to find deeper observations, you must first, 'force yourself to see more flatly' (1997:51).

With these observational frameworks in 
mind, I return to the various taxonomies of the senses, and in particular the work of James Gibson in The Senses Considered as Perceptual Systems. This work is widely cited in Malnar \& Vodvarka's comprehensive work on Sensory Design and offers a model of the senses which considers them as active modes of attention. This rejects many of the assumptions of psychological studies of the senses, where experiments are conducted on passive subjects robbed of any context for the sensations experienced. This lack of context is essential for the scientific method to operate, but it misses several of the fundamental features of perception: that it is attentive and active, and that it is always within a specific context. We see in places and spaces, we perceive in the environment and are always a part of it.

These attentive systems of perception are arranged slightly different to the traditional notion of five senses we have in the West: Sight, Hearing, Taste, Smell and Touch. Instead, Gibson gives us the Basic Orienting System, Auditory System, Haptic System, Taste-Smell System and the Visual System. Each is given a mode of attention, receptive units, anatomical details of the organ, the activity of the organ, the stimuli available and an account of what external information is obtained.

\section{Laban Notation, Deriva- tions from Effort \& Shape Ma- trices}

One system of notation of particular interest is Laban movement notation [18]. This notation is most commonly used in the notation of modern dance and ballet, but remains a contentious way of understanding movement amongst professional choreographers, dancers and notators. This is due to the notation's strength in imposing an un- derstanding and theory of the movement of the human body onto how it is represented. This is no different to the way in which any form of inscriptive practice imprints some form of accepted understanding onto what it represents: no form of inscription is neutral.

One feature of Laban notation of particular interest is the effort and shape matrix. This is one small part of Laban [19] which is used to depict qualities of a movement, where the main notation scripts the direction and specific parts of the body in motion, the effort matrix tells the dancer more detail on a given instruction.

The matrix notation is particularly elegant and efficient as a means for giving this information, depicting a series of axes of opposed terms, the notator draws only the elements of the matrix required for that instruction.

The first attempt I made to design a notation for the senses drew heavily upon this system, establishing a matrix for each sense and relating these phenomena to a plan drawing. The spatial extent of each sensation was depicted through a variation of Kevin Lynch's famous Imageability [20] symbols which describe urban spaces in terms of paths, nodes, landmarks, districs and edges (Lynch 1990:18)

This notation was tested with our advisory board, and met with mixed reactions. Valuable lessons were learned through this process of design and testing, however, that lead to the development of the subsequent system. The matrix notation does, however, remain an option for development as it has the benefit of being graphic in nature, with a finite range of variables that can be learned through use. The layering and relation to other forms of description such as Lynch remains at the heart of the system as a way for describing the essential qualities of urban space. Other tools such as Section drawings depicting volumes such as those found 
in Allan Jacobs [21], the serial drawing of Gordon Cullen [22], the play of public and private space or even the Situationist Drift of Guy Debord [23].

\section{Radar Notations, Routes and Sites}

The notation system itself is only one part of the process, of course. Ordering the perception itself is also necessary, in order for the best to be gained out of the diagram. The following is being tested with the collaboration of groups of senior undergraduate and Masters students in a variety of disciplines from architecture, urban design, product design, anthropology and sound design.

These workshops focus on the radar diagram method described above, but in a structured way. The notations were conducted in two main ways. First of these is to

\begin{tabular}{lllllll}
\hline VISUAL & AURAL & TACTILE & KINETIC & THERMAL & CHEMICAL \\
\hline Dark & High Pitch & Static & Strong & Hot & Weak \\
Bright & Low Pitch & Mobile & Light & Cold & Intense \\
\hline Saturated & Quiet & Rough & Free & Dry & Stagnant \\
\hline Neutral & Loud & Smooth & Bound & Wet & Fresh \\
\hline $\begin{array}{l}\text { Perspectival } \\
\text { Flat }\end{array}$ & Clear & Light & Indirect & Natural & Musky \\
\hline Intimate & Reverberant & Heavy & Direct & Artificial & Putrid \\
\hline Vast & Non-Vocal & Resistant & Graded & Source & Fruit \\
\hline Solid & Natural & Hard & Sustained & Radiant & Spice \\
Void & Artificial & Soft & Quick & Convective & Resin \\
\hline Detailed & Attack & Warm & Crowded & Constant & Meaty \\
Blank & Decay & Cold & Empty & Responsive & Oily \\
\hline
\end{tabular}

Table 2: Descriptor terms.
Location: plot the site being recorded, whether a part of a route or a static position. Details such as time, date and weather may also be included.

Priority: draw a line on the chart corresponding to the priority given to that perceptual system in this context.

Corroboration: indicate how the senses overlap.

Temporality: indicate the repetition, singularity, etc. of the observations. 
Descriptor: use a word from the list given to characterise each of the six perceptual systems: visual, aural, olfactory/gustatory, tactile, thermal, kinaesthetic.

By locating the site on a traditional drawing such as a plan or section, the notational scheme can be understood as a layer or transparency added to traditional modes of depicting urban spaces. This is an important step, as it identifies the process as part of the traditional toolkit, rather than completely alien to it. Additional information such as time, date and weather conditions are necessary for the future usefulness of the record, as the sensory data vary widely depending upon the time of day or the season.
The next step is to place a descriptor word on each of the six perceptual systems employed by the notation. These are chosen from a restricted and carefully selected list of words for each sense. The terms are chosen for their clarity and lack of metaphorical content. This precision of language finds its roots in Laban notation's Effort and Shape matrices, where a very tight use of language helps to describe quite complex movements. Similarly, a lesser known system of movement notation, Saunders Notation (Hutchinson-Guest 1989:xx). Additionally, names of things causing particular sensations such as traffic or wind may be added if the notator feels it necessary.

The third step in the notation is the main graphic step: priority. This step is subjective by its very nature, but it offers a strong

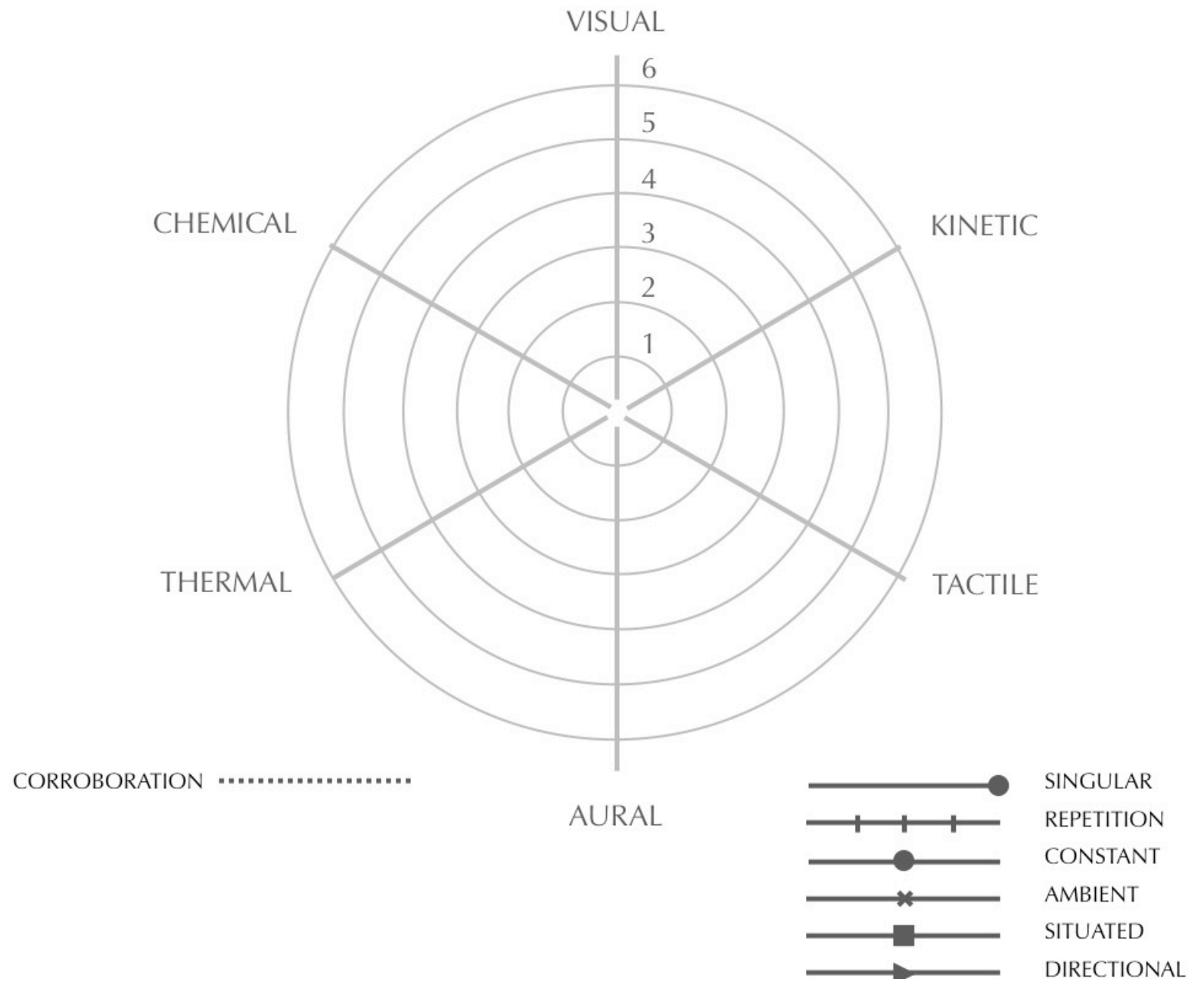

Figure 1: Key to Sensory Notation 
picture of each environment as well as suggesting immediate ways in which the environment may be changed. This step consists of deciding which senses are strongest, most affective and prominent. The senses are then ranked in order of priority. This is drawn in an order of priority rather than introducing artificial constructs such as the percentage of the sensorium devoted to that sense. The Radar chart is drawn with numbers from 1 to 6 , outside to inside. The highest priority is placed at one, the least at six. There is flexibility within this, of course, allowing some senses to be placed at the same rank as each other, or the gulf between two perceptual systems to be depicted as larger or lesser as appropriate.

The next, optional step, is to depict the corroboration between the senses by using curved, dotted lines between the different senses. These lines can contain a variety of data about this relationship, but the main thrust is to efficiently describe where these overlaps occur without overloading the diagram.

The final step recognises the temporality of the senses, and adds indications to the main Radar diagram lines of the quality of time inherent to that sense. This can be persistent, repetitive, singular, rhythmic or intermittent. This notation is not necessarily timed using chronological time, but rather recognises the phenomenological basis of the notation. The conceptualisation of time in this regard is experienced time rather than the clock time of the physical sciences.

The diagrams are collected and analysed in a number of different ways. The route notations can be layered, showing the progress along a path through transparency. This allows the route to be understood in terms of how the senses change from one position along the path to another. This can aid in identifying the prominent sensory stimuli on each route, where there are deficits, and what makes this trail unique in character. Similarly, the static locations can be reviewed and understood, particularly where a body of people have taken a record of the same place under similar conditions.

These observations are collated, so that patterns may emerge. These patterns are understood in the same way as Christopher Alexander's Pattern Language with a different slant: the sensory experience of place. Of course, Alexander's work has been deployed differently by a variety of academic disciplines over the years. One example is the adoption of his work by computing science as a model for how creativity and design works. This is a false picture, however, and is attractive to that discipline precisely because it is easily understood through computational models. Other uses have included rather reactionary movements in urbanism which use Alexander's patterns as a justification for pursuing a purely historicist agenda, rejecting everything the 20th Century and Modernism had to offer. This is not to devalue Alexander's approach of course, as it certainly has its place and is of intense interest. A new pattern book is being assembled using the Sensory Notation method, not as absolute models, but as suggestions and examples to be played with and designed with freely, but in an informed way. Patterns will include public squares, fountains, gardens, thoroughfares, boulevards, arcades, steps, subway entrances, and many more.

These patterns can be used as given or adapted freely as required by the designer. The patterns give help to designers looking to create urban spaces, offering short-cuts and opportunities for designing richer multimodal environments. The notation can be used to record existing sites and diagnose problems with them, or offer rich descriptions of desirable places for the construction of completely new sites. The toolkit shall be distributed in printed form and consist 
of the Sensory Notation system and Sensory Pattern Book [24] as well as detailed essays on the importance of the senses in urban design.

\section{End Notes}

1. Ruskin, John. 1971. The Elements of Drawing. New York: Dover Publications.

2. Pallasmaa, Juhani. 1996. The Eyes of the Skin: Architecture and the Senses. London: Academy Editions.

3. I have argued this in far greater detail in my PhD thesis, Lucas, R. 2006. Towards a Theory of Notation as a Thinking Tool. Aberdeen: Department of Social Anthropology, University of Aberdeen.

4. Goodman, Nelson. 1976. Languages of Art. Indianapolis: Hackett Publishing Company Inc.

5. Again, this is considered in greater depth with reference to the work on the temporality of creativity by philosopher Henri Bergson in my PhD thesis (Lucas 2006).

6. Bergson, H. 1992. The Creative Mind: An Introduction to Metaphysics. Andison, M. L. Trans. New York: Citadel Press.

7. Borges, J L. 1999. A Universal History of Iniquity. Trans. A Hurley. London: Penguin.

8. Tanizaki, J. 2001. In Praise of Shadows. T J Harper \& E G Seidensticker (Trans.). London: Vintage.

9. Ingold, T. 2000. Perception of the Environment. London: Routledge.

10. Zumthor, P. 2006. Atmospheres. Basel: Birkhäuser.
11. Blesser, Barry and Salter, Linda-Ruth. 2007. Spaces Speak, Are You Listening? Experiencing Aural Architecture. Cambridge Massachusetts: MIT Press.

12. Augoyard, Jean-François and Torgue, Henry (Eds). 2005. Sonic Experience: a Guide to Everyday Sounds. Montreal \& Kingston: McGill-Queen's University Press.

Augoyard, Jean-Françcois. 2007. Step by Step: Everyday Walks in a French Urban Housing Project. David Ames Curtis Trans. Minneapolis: University of Minnesota Press.

13. DeNora, Tia. 2000. Music in Everyday Life. Cambridge: Cambridge University Press.

14. Bull, Michael. 2000. Sounding Out the City: Personal Stereos and the Management of Everyday Life. Oxford: Berg.

15. Lefebvre, H. 2004. Rhythmanalysis: Space, Time and Everyday Life. New York: Continuum.

16. Perec, Georges. 1997. Species of Spaces and Other Pieces. London: Penquin Books.

17. Gibson, James J. 1996. The Senses Considered as Perceptual Systems. Boston: Houghton Miffin Company, p.66

18. I deal with this form of notation as well as other movements in more detail in my PhD thesis (Lucas 2006). This includes examples of Laban notation of scenes from Kurosawa's Seven Samurai, notation as a script for a drawing, and an extended project looking at the Tokyo Subway system, using Laban as a model for describing the experience of urban space.

19. Dell, Cecily.1977. A Primer for Movement Description Using Effort-Shape and 
Supplementary Concepts. New York: Biography
Dance Notation Bureau Press.

20. Lynch, Kevin. 1990. The Image of the City. Cambridge, Massachusetts: MIT Press.

21. Jacobs, Allan B. 1995. Great Streets. Cambridge, Massachusetts: MIT Press.

22. Cullen, Gordon. 1971. The Concise Townscape. Oxford: Architectural Press.

23. See the wide literature on this, particularly: Sadler, Simon. 1998. The Situationist City. Cambridge, Massachusetts: MIT Press.

24. Lucas, R. 2008. Sensory Notation Handbook. Edinburgh: Flâneur Press.

Ray Lucas is Postdoctoral Research Fellow on the AHRC/EPSRC Designing for the 21st Century project 'Multimodal Representations of Urban Space'. This research is looking at developing new notational systems for urban design that respond to our whole experience of space. This includes notations for the different senses, movement through space, the feel of space and more. The project intends to test these notations and to publish a design guide to encourage multimodality in urban design.

Lucas recently worked as Postdoctoral Fellow at the University of Edinburgh on a collaboration between Music and Architecture entitled 'Inflecting Space'. The project examined the capacity and extent of the human voice to transform and define public spaces.

Lucas has a PhD research in Social Anthropology at the University of Aberdeen, and examined the role of notation and inscriptive practices such as drawing as cognitive processes. Prior to this, Lucas gained an MPhil by research at the Department of Architecture, University of Strathclyde in Filmic Architecture, examining the relationship between cinematic montage and architecture.

From January 2009, Lucas will be working on "Cultures of Legibility', a research project based at the Departments of Architecture and Geography, University of Edinburgh. The project will examine migration and representation in Jakarta, Indonesia. 